\title{
Resistivity Measurement of Silicon Crystals Irradiated by Reactor Neutrons ${ }^{\dagger}$
}

\author{
Kiyohisa FuJINAgA* \\ Ibaraki Electrical Communication Laboratory, Nippon Telegraph \\ and Telephone Public Corporation, Tokai, Ibaraki, Japan \\ Received July 19, 1979
}

Key Words: phosphorus doping, neutron irradiation, silicon crystals, impurities, neutron activation analysis, damage, resistivity change, annealing

\section{Introduction}

Phosphorus doping into silicon crystals by means of thermal neutron irradiation is a very effective method of producing silicon semiconductor with a homogeneous resistivity distribution and any desired resistivity level. ${ }^{1)}$ The doping process is based on the reaction:

$$
{ }^{30} \mathrm{Si}(n, \gamma){ }^{31} \mathrm{Si} \stackrel{2.62 h}{\longrightarrow}{ }^{31} \mathrm{P}+\beta^{-}
$$

Irradiated silicon crystals are heavily damaged and electrical resistivity changes drastically. The lattice damage can be removed by an appropriate annealing. The change in resistivity of the silicon crystals is quite complex. It depends on both impurity atoms contained originally in silicon and atoms produced by nuclear reactions.

This note describes the determination of impurities originally contained in $\mathrm{FZ}$ and $\mathrm{CZ}$ silicon crystals by means of neutron activation analysis and the measurement of change in resistivity of irradiated and/or annealed silicon crystals.

\section{Experimental}

An investigation was made of silicon crystals

†原子炉中性子により照射されたシリコン結晶の抵 抗率の測定. 藤永清久: 電電公社武蔵野電気通信 研究所, 180 東京都武蔵野市緑町 3 丁目

* Present address: Musahino Electrical Communication Laboratory, Nippon Telegraph and Telephone Public Corporation, Midori-machi, Musashino-shi, Tokyo 180, Iapan. with oxygen concentrations known by infrared spectroscopy: (1) FZ, n-type doped with phosphorus, $3000 \Omega \cdot \mathrm{cm}$, oxygen concentration $<2 \times$ $10^{15} \mathrm{~cm}^{-3}$; (2) $\mathrm{CZ}$, n-type undoped, $200 \Omega \cdot \mathrm{cm}$, oxygen concentration $7 \times 10^{17}$ and $1.1 \times 10^{18} \mathrm{~cm}^{-3}$. The samples were irradiated for $20 \mathrm{~min}-265 \mathrm{~h}$ in the nuclear reactor JRR-3 at the Japan Atomic Energy Research Institute. The thermal neutron fluxes at the sample location were estimated from cobalt monitors which were irradiated close to the samples. After irradiation, the samples were cooled to decay the activity of ${ }^{31} \mathrm{Si}$ and etched in a mixture of $\mathrm{HNO}_{3}$ and $\mathrm{HF}$ to remove radioactive impurities on the surface.

The determination of impurity concentration in the samples was carried out by the single comparator method based on non-destructive neutron activation analysis with a $\mathrm{Ge}(\mathrm{Li})$ gamma-ray spectrometer. The analytical method is described in detail elsewhere ${ }^{2)}$.

Resistivity of the irradiated samples was measured with a four-point probe equipment before and after annealing. The annealing treatment was done for $3 \mathrm{~h}$, using a quartz furnace tube at $900^{\circ} \mathrm{C}$ in nitrogen atmosphere. ${ }^{3)}$

Not irradiated silicon crystals were annealed to check resistivity changes caused by accidental contamination during the heat treatments.

\section{Results}

Table 1 shows the impurity concentrations in $\mathrm{FZ}$ and $\mathrm{CZ}$ silicon crystals determined by neutron activation analysis. 
Table 1 Impurity concentrations in silicon crystals

\begin{tabular}{l|r|r|r|r}
\hline \multirow{2}{*}{$\begin{array}{l}\text { Silicon } \\
\text { crystal }\end{array}$} & \multicolumn{4}{|c}{ Impurity concentration } \\
\cline { 2 - 5 } & $\mathrm{O}\left(\mathrm{cm}^{-3}\right)$ & $\mathrm{Co}(\mathrm{ppb})$ & $\mathrm{Cu}(\mathrm{ppb})$ & $\mathrm{Na}(\mathrm{ppb})$ \\
\hline $\mathrm{FZ}$ & $<2 \times 10^{15}$ & $<0.007$ & 1.7 & 1.4 \\
$\mathrm{CZ}-1$ & $1.1 \times 10^{18}$ & 0.010 & 0.2 & 0.2 \\
$\mathrm{CZ}-2$ & $7 \times 10^{17}$ & 0.014 & 0.3 & $<0.1$ \\
\hline
\end{tabular}

The very small amounts of cobalt, copper and sodium were analyzed by the single comparator method on the basis of the isotopes ${ }^{60} \mathrm{Co},{ }^{64} \mathrm{Cu}$ and ${ }^{24} \mathrm{Na}$ detected in gamma-ray spectra, respectively. No other elements were found above the detection limits. This indicates that the silicon crystals used here were of very high purity.

Activities in the silicon crystals are caused by nuclear reactions with silicon, impurities and dopants. The activities of ${ }^{31} \mathrm{Si}$ (half-life $2.62 \mathrm{~h}$ ), ${ }^{64} \mathrm{Cu}(12.8 \mathrm{~h})$ and ${ }^{24} \mathrm{Na}(15.0 \mathrm{~h})$ decay almost completely after a few days. The activity of ${ }^{60} \mathrm{Co}(5.2 \mathrm{y})$ is $8 \times 10^{-6} \mu \mathrm{Ci} / \mathrm{g}$ when silicon containing $0.01 \mathrm{ppb}$ cobalt is irradiated for $265 \mathrm{~h}$. This value is much lower than the exempt limit of $2 \times 10^{-3} \mu \mathrm{Ci} / \mathrm{g} .{ }^{4)} \quad$ The activity of ${ }^{32} \mathrm{P}(14.2 \mathrm{~d})$ arising from nuclear reaction with phosphorus in silicon crystals remains radioactive for several months because of its relatively long half-life. As is well known, this is not serious problem if a longer decay period is taken.

The resistivity of irradiated FZ silicon crystals without any annealing treatments is shown in Fig. 1. All samples presented high resistivity values of $4-6 \times 10^{5} \Omega \cdot \mathrm{cm}$ due to the lattice damage. The damage was caused by irradiation

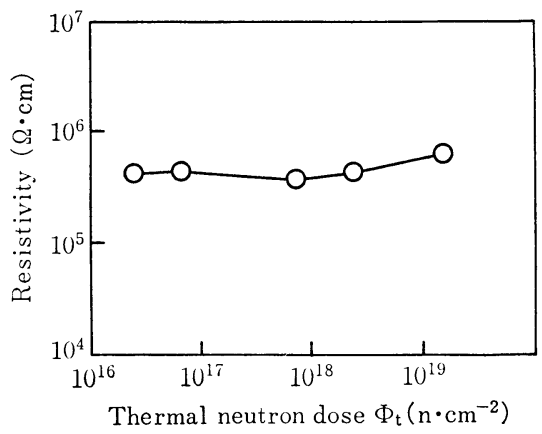

Fig. 1 Resistivity of neutorn-irradiated FZ silicon crystals. effects-fast neutrons, recoil atoms, gamma bombardment and beta decay. The values did not depend on the thermal neutron dose $\Phi_{t}$ $\left(\mathrm{n} \cdot \mathrm{cm}^{-2}\right)$.

The resistivity of $\mathrm{FZ}$ and $\mathrm{CZ}$ silicon crystals measured after irradiation and an annealing treatment at $900^{\circ} \mathrm{C}$ for $3 \mathrm{~h}$ is shown in Fig. 2 . Phosphorus concentration $N_{p}\left(\mathrm{~cm}^{-3}\right)$ produced by the nuclear reaction (1) is calculated from the equation ${ }^{5)}$ :

$$
N_{p}=1.7 \times 10^{-4} \Phi_{t}
$$

The resistivity is given by $N_{p}$ plus the impurity concentration of the starting material. It was found from Fig. 2 that the resistivity obtained in FZ silicon crystals was inversely proportional to the total phosphorus concentration in the range of $1-10^{3} \Omega \cdot \mathrm{cm}$ and was in good agreement with Irvin's curve. ${ }^{6)}$ This fact suggests that the annealing treatment was suitable for obtaining the lattice recovery. For the resistivity of $\mathrm{CZ}$ silicon crystals, the results were a little lower than Irvin's curve. No significant difference in resistivity was found between CZ1 and CZ-2, although Mordkovich, et al. indicated that resistivity depended on concentration of oxygen in $\mathrm{CZ}$ silicon crystals. ${ }^{\text {") }}$ It is concluded that resistivity of $\mathrm{FZ}$ silicon crystals can be exactly controlled, but that of $\mathrm{CZ}$ silicon crystals not so easily controlled; it is necessary to investigate further the resistvity of irradiated and/or annealed $\mathrm{CZ}$ silicon crystals.

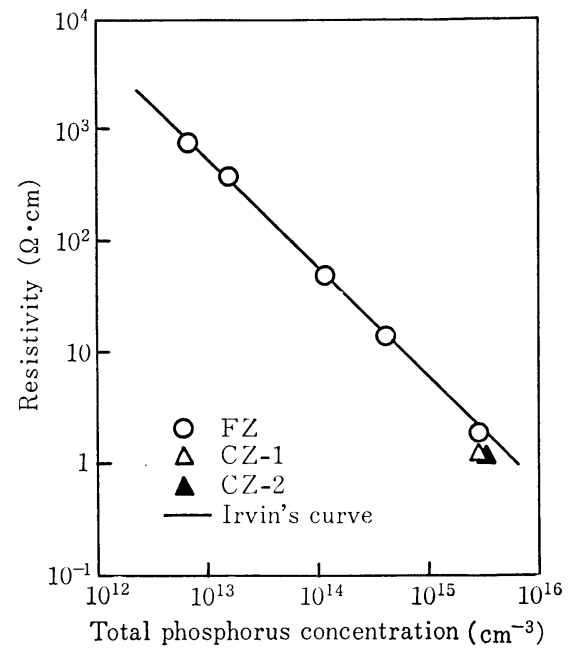

Fig. 2 Relation between total phosphorus concentration and resistivity of irradiated and annealed silicon crystals. 
The author wishes to thank Dr. N. Niizeki and Dr. K. Kudo for encouragement throughout this work and also thank Dr. M. Kondo for valuable discussions on writing the note.

\section{References}

1) M. Tanenbaum and A.D. Mills: J. Electrochem. Soc., 108, 171 (1961)

2) K. Fujinaga and K. Kudo: Analytica Chimica Acta, 110, 75 (1979)

3) M.J. Hill, P.M. Van Iseghem and W. Zim- mermann: IEEE Trans. Electron Devices, ED-23, 809 (1976)

4) H.M. Janus and O. Malmros: ibid., ED23, 797 (1976)

5) A. Yusa, Y. Yatsurugi and T. Takaishi: J. Electrochem. Soc., 124, 312 (1977)

6) J.C. Irvin: Bell System Tech. J., 41, 387 (1962)

7) V.N. Mordkovich, S.P. Solov'ev, É.M. Temper and V.A. Kharchenko: Sov. Phys. Semicond., 8, 139 (1974) 